\title{
Kültürel Mirasın Gelecek Kuşaklara Aktarılması ve Tanıtımında Yazma Eser Kütüphaneciliği
}

\author{
FATIH RUKANCI*
}

\begin{abstract}
ÖZ
Kültürel miras, medeniyet tarihi boyunca yaşamın her kesitine ve alanına dair ürünlerinden geleceğe intikal değeri taşıyanlarını ilgilendiren oldukça kapsamlı ve yoruma açık bir kavram olarak gündemdeki yerini korumaktadır. Bu ürünler ya da üretim; geçmişi doğru algılamamıza, yorumlayabilmemize dayanak oluşturan önemli tecrübe, birikimlerden yararlanabilmemizi de olanaklı kılmaktadır. Kapsam insanlığın ortak geçmişi olduğunda ise kültürel miras ürünleri bir yönüyle ait oldukları medeniyeti temsil ederken diğer yönüyle tüm insanlığın ortak birikiminin tamamlayıcı parçaları olarak evrensel bir değer taşımaktadır. Yazma eserler kültürel miras yelpazesinin orijinal yazın ürünleri olarak, aslında geçmişteki kodlarımızı bize en iyi tanıtan bir birikim / külliyat ve ecdat emanetidir. Yeni nesil ile tanıştırma ve geleceğe intikalini sağlama sorumluluğunu üstlenmemiz gereken bu kaynaklar, nadir ya da tek nüsha olmalarından kaynaklanan değerlerinin yanı sıra sahip oldukları bilgi / içerik ve sanatsal özellikleriyle de özel bir ihtisası / ilgiyi fazlasıyla hak etmektedir. Kültürel mirasın bu önemli kaynaklarını uluslararası standartlarda tanımlamak ve tanıtımını sağlayabilmek basılı kaynaklara oranla daha zahmetli ve işbirliği içinde yürütülmesi gereken bir bilimsel çalışmayı zorunlu kılmaktadır. Bu nedenledir ki kütüphanecilik biliminin içinde yazma eser kütüphaneciliği de ayrı bir uzmanlık dalı olarak görülmelidir. Yazma eser kütüphaneciliğinin kültürel miras ürünleri olan yazma ve nadir eserlerimizin geleceğe aktarımı ve tanıtımında ne denli stratejik bir rol oynadığının tartı̧̧ıldığı çalışmada aynı zamanda yıllardır süregelen birtakım yanlış algı ve uygulamalara da değinilecektir.
\end{abstract}

Anahtar sözcükler: Kültürel Miras, Yazma Eserler, Nadir Eserler, Yazma Eser Kütüphaneciliği, Kullanıcı Hizmetleri

* Prof. Dr. Ankara Üniversitesi, Dil ve Tarih Coğrafya Fakültesi, Bilgi ve Belge Yönetimi Bölümü, Ankara/Türkiye E-posta: frukanci@gmail.com

Makale Gönderim Tarihi: 05.02.2018 • Makale Kabul Tarihi: 04.06.2018 


\section{ABSTRACT \\ Manuscript Librarianship in Transferring and Introducing Cultural Heritage to Next Generation}

Cultural heritage preserves its place on the agenda as a very comprehensive and open-ended concept that deals with the values of the future for its products from all aspects and parts of life throughout the history of civilization. It is also possible that we can benefit from the accumulation of these products or production, in terms of perceiving and interpreting the past accurately. Where coverage is the common history of mankind, cultural heritage products represent a civilization to which they belong on one hand, while they carry universal value as complementary parts of the common accumulation of humanity on the other hand. Manuscripts are the products of the original genre of the cultural heritage, in fact a background of knowledge, corpus and consignation of ancestry that best introduces us to our past codes. These resources, which we have to assume responsibility for introducing to the new generation and ensuring their conveyance to future, deserve to have special or extraordinary value with their knowledge / content and artistic characteristics as well as their value due to being a rare or unique copy. To be able to identify and publicise these important resources of cultural heritage at international standards requires more exhausting scientific study which should be carried out in cooperation compared to printed sources. It is for this reason that manuscript librarianship should also be seen as a separate area of expertise. In the study where the discussion point is the strategic role of manuscript librarianship in introduction and conveyance to future of cultural heritage products, namely manuscripts and rare pieces of art, ongoing false perceptions and applications will also be emphasized.

Keywords: Cultural Heritage, Manuscripts, Rare Books, Manuscripts Librarianship, User Services

Y

azma eserler, arşiv belgeleri ile birlikte bilimsel/kültürel geçmişimize dair sağlıklı bilgiler edinebileceğimiz yazılı kaynaklar arasında ilk iki sırayı almaktadır. Buna rağmen yazma eserlerimizin uluslararası standartlar ve kendi özgü değerleri çerçevesinde nitelenmesine ilişkin Türkçe literatür ve başvuru kaynağı oldukça sınırlıdır. Özellikle yazma eserlerimizin zengin içeriği ve konu çeşitliliği dikkate alındığında konuyla ilgili detaylı bir konu başlığı listesi / dizini, müellif ve eser adı dizinlerinin henüz oluşturulmamış olması bu alandaki çalışmalara bilimsel bir bakış açısıyla yaklaşmamız gerektiğini gözler önüne sermektedir. Bu bağlamda bu makalenin temel varsayımı 
yazma eser kütüphaneciliğinin ülkemizde başta kütüphanecilik olmak üzere ilgili birçok disiplinin işbirliği ve koordinasyonu çerçevesinde yürütülmesi gerekli olan bilimsel bir faaliyet olduğunun yeterince anlaşılmamasıdır.

Bilgi kayıt ortamı olarak kâğıdın ve diğer yazı malzemelerinin ve hatta okuryazarlığın son derece sınırlı olduğu dönemlerde birçoğu büyük bir sabır ve ustalıkla üretilmiş olan bu "yaşlı kitaplar" kültürel mirasımızın geleceğe aktarımında yerine başka bilgi aktarım kaynağını koyamayacağımız eserlerdir. Yazma ve nadir eserler her şeyden önce kültürümüzdeki "kitap" kavramı hakkında birçok bilgi edinmemizi sağlayarak kitaba olan bakış açımızı değiştirebilir. Bunun yanı sıra günümüzdeki "kitap” anlayışı ile oldukça farklı bir anlayı̧ içinde üretilen yazma eserlerin üretim tarzının, bugün kütüphanecilerin yazma eser kataloglama faaliyetlerini oldukça zorlaştırdığ 1 da bir gerçektir. Sahip olduğumuz yazma eserlerin Türk-İslam medeniyetindeki kitap yazma geleneğinin temsilcileri olduklarını söylemek belki de bu konuda yapılabilecek ilk ve önemli tespit olarak değerlendirilebilir. Çünkü bu anlayış ve gelenek bugün unutulmaya yüz tutmuş bazı ortak kültürel değerleri ve hassasiyetleri de bize hatırlatmaktadir.

Türk-İslam medeniyeti kitap yazma geleneğinde tek kelime ile kitap ve kitabi bilgi “kutsal” dır. Ayrıca kitap yazmak, kitabın içeriğinden sorumlu olmak çok ağır ve önemli bir sorumluluktur. Birçok yazma eserdeki iç düzen bu bağlamda birbirine benzerlik gösterir. Esere besmele ile başlanır, Allah'a hamd ve şükür ifadelerinden hemen sonra Hz. Muhammed'e mübarek soyuna ve ashabına salat ve selam cümleleri hem müellifi hem de okuyucuları kitabın ve bilginin ulûhiyetine hazırlar. Hamdele ve salvele adı verilen bu bölümler modern kitaplarda yer almazken; bunların yerini önsöz, teşekkür, giriş, bölümleri almıştır. Bu bölümlerde esere katkı yapanlar, eserin ilham kaynağı eser ve kişiler, eserin hedef kitlesi, yazılış nedeni gibi açıklama ve minnet ifade eden yazılar karşımıza çıkmaktadır. Bu durumda gelecek kuşaklar yazma eserler ile tanıştırılmaz ise, yeni neslin kültürel geçmişimizde kitaba atfedilen bu yüce manayı algılamakta zorluk çekmeleri kaçınılmazdır.

Türk-İslam medeniyetindeki kitap yazma tarz ve geleneği kendine özgü terminolojiyi de beraberinde getirmiştir. Örneğin, çoğunluğu Arapça ve Farsça yazılan eserlerin kitap bölümleri fasıl, bab, kısım olarak isimlendirilmiştir. Bunun yanı sıra eğer yazma kitabın fiziksel ve sanatsal özelliklerini tanımlıyor isek; güneş biçimindeki cilt kapağı süslemesini "şemse", cildin dikiş kısmını "şiraze”, cilt kapaklarını "deffe", sayfa kenarı notlarını "derkenar", "haşiye”, eserin ilk yapraklarını "zahriye", metnin giriş bölümlerini "dibace", son bölümünü ise "hatime" olarak ifade etmek durumundayı. Bu terminoloji, 
eserin nitelenmesinde ortak bir dil kullanılarak nitelemenin kişiye bağlı kalınmaksızın anlaşılır hale getirilmesi açısından oldukça önemlidir. Yazma eser literatüründeki bu terminoloji aynı zamanda bilimsel/sanatsal yazın ürünlerinde ve bunların oluşturulma ve sunum biçimlerinde kültürel etkileşimin ne kadar yoğun yaşandığının da bir kanıtıdır. Türkiye'de söz konusu terminolojinin ortak kullanımı için hazırlanmış "yazma eser terimleri” sözlük girişimleri birbirinden bağımsız olarak kişisel ya da örgütsel girişimler olarak ortaya çıkmış ise de bu sözlüğün hazırlanması ve denetiminden yasal olarak sorumlu kurum Türkiye Cumhuriyeti Kültür ve Turizm Bakanlığı'na bağl1 Yazma Eserler Kurumu Başkanlığı'dır. Söz konusu kurumun, alan uzmanları/akademisyenlerden oluşan bir komisyon çalışması ile yazma eser terimleri sözlüğü hazırlayıp hem basılı hem de elektronik olarak erişime sunması, ülkemizde yazma eser terminolojisinin, yazma eserlere özgü ortak bir dilin yaşatılması ve gelecek kuşaklara aktarılması açısından oldukça önem taşımaktadır.

Yazma eserleri, baskı/matbu eserlerden farklı k1lan özellikler temelde onların her bir nüshasının birbirinden ayrı nitelikler taşıması ve her biri için çoğu zaman birden çok kişinin (müellif, mütercim, müstensih, hattat, musavvir, şarih, muhaş̧̧i, müzehhip, mücellit gibi) yoğun emek sarf etmiş olmasıdır. Herhangi bir yazma eserde meydana gelebilecek kısmi ya da bütüncül kayıplar ise onların nadir ya da tek nüsha oldukları düşünüldüğünde, telafisi mümkün olmayan olumsuz bir durumla karşılaşılmasına yol açmaktadır. Bu nedenledir ki içeriğinin ötesinde yalnızca bir yazma kitabın dahi fiziksel ve sanatsal özelliklerinin yansıtılarak korunması, kullanıcıya arzı çoğu zaman birçok alanda uzmanlık gerektiren zahmetli bir çalı̧mayı gerektirir.

Kültürel mirasımızın en kıymetli bütünleyicilerinden yazma eserlerimizin ülkemizde henüz tam anlamıyla kontrol altına alınabildiğini söylemek mümkün değildir. Özellikle geçmişten günümüze varlığını sürdüren eğitim kurumları, ibadethaneler, vakıflar, dernekler ve özel derme/koleksiyonlarda kimi zaman tesadüfen karşımıza çıkabilmektedir. Bunun nedenlerini dönemin Milli Kütüphane Genel Müdürü Müjgan Cunbur şu ifadelerle açıklamaktadır:

"Bir yandan kültür merkezlerinden çok uzak yerlere kadar kütüphane açma geleneğinin yayılışı yazma eser koleksiyonlarının dağılışında amil olurken, diğer yandan Türkiye'ye matbaanın birkaç asır gecikme ile girişi ve yavaş gelişimi, yazma kitap devrinin memleketimizde daha da uzamasına, bunun sonucu olarak koleksiyonların daha da artmasına sebebiyet vermiştir. Yazma eser koleksiyonlarının çokluğu ve yurt sathındaki yaygınlığı, bu tip eserlerin günümüzde de en büyük üniversite ve araştırma kütüphanelerinden küçük 
ilçe halk kütüphanelerine kadar pek çok yerde bulunmasında rol oynamışır." (Cunbur 1970: 3).

Yazma eserlerin bibliyografik denetimini ya da yazma eser kütüphaneciliğini zorlu kılan nedenler arasında bu tarihi eserlerin dağınıklığının yanı sıra alfabesinin/yazısının okunmasındaki güçlük, kondisyonlarının iyi durumda olmaması ve içeriğinin çok farklı uzmanlık alanları (tarih, edebiyat, sanat tarihi, ilahiyat, doğu dilleri, kütüphanecilik gibi) ile işbirliği içinde çözümlenebilmesi zorunluluğu sayılabilir.

Üzülerek belirtmeliyim ki yazma eserlere ilişkin 40-50 y1 öncesine ait olan bu ifadeler bugün de güncelliğini korumaktadır. Bunun temel nedeni yazma eser kütüphaneciliği ile ifade edebileceğimiz bir disiplinin ülkemizde sürdürülen yaklaşık 60 yıldır üniversite düzeyindeki kütüphanecilik eğitimi içinde hak ettiği yeri bulamamış olması ya da böyle bir disiplinin varlık nedeni ve gerekliliğinin tam olarak anlaşılamamasıdır. Bu durumun diğer nedenleri 2010 yılı sonunda kurulan Yazma Eserler Kurumu Başkanlığı'nın bilimsel bakış açısından uzak hamaset dolu yaklaşımlar nedeniyle "bütün yazma eserlerimiz eşsizdir, hazinedir, çok kıymetlidir”, sloganlarıyla tıpkıbasımlar ve yeni nesil bir depo eşliğinde yazma eser kütüphaneciliği dışındaki çalışmalarına devam ediyor olmasıdır. Kütüphane yöneticilerinin tabiri caizse enkaz devralması, bu enkazı iyileştirme çalışmalarına ağırlık ve öncelik vermesi, detaylı kataloglama yapabilecek nitelikli yazma eser uzmanı ya da kodikolog bulunmaması ve belki de en önemlisi yazma eser kütüphanelerinde çoğunlukla yazma eserleri yalnızca okuyabilen personelin baş tacı edilerek kütüphanecilik mesleğinin hiçe sayılması bunun temel nedenleri arasında sayılabilir.

Bazı yazma eserlerin nadir olma özelliklerine bir de üzerindeki eşsiz güzellik ve estetiğe sahip süslemeler (tezyinat) eklendiğinde yazma eserlerin, özenle korunarak gelecek kuşaklara aktarılması gerekli kültür hazineleri / mirası arasında yerini almış olması son derece doğaldır. Yazma eserlere kültürel miras niteliği kazandıran unsurları genelde ve özelde iki farklı grup altında toplayabiliriz. Bu unsurlar genelde:

* Bazı yazma eserlerin medeniyetimize ilişkin sosyal-bilimsel-kültürelentelektüel-geleneksel birikimi barındırıyor olmasi; Toplumun gelecek kuşaklara aktarmak istediği ya da istemediği "kimlik bilinci" için başvurulması gereken orijinal bilgi kaynaklarının önemli bir parçası olması,

* Bu eserlerin nadir ya da tek nüsha olmalarından kaynaklı kültürel miras kapsamına alınarak materyale özel korumaya ve saklamaya tabi tutulması gereksinimi, 
* Bazı yazma eserlerin içeriğinde yer alan, günümüzde ve gelecekte tüm insanlığa faydalı olacak (unutulmaya yüz tutmuş ve unutturulmak istenen) her tür bilgi ve mesajların anlaşılması ve yaşatılması sorumluluğu olarak siralanabilir.

Özelde ve detayda ise, bazı yazma eserleri kültürel miras kapsamına alan özellikler oldukça fazladır:

* Yazma eserlerin cildinin materyali, süsleme unsurları ve sanatları kendine özgü terminolojiyi oluşturacak kadar özgün ve çeşitlidir: deffe, şemse, miklep, sertab, şiraze, zencirek, salbek, köşebent bu terimlere örnek olarak verilebilir,

* Kitap üzerindeki ve içindeki kayıtlar ve mühürler: temellük, sem'a, mukabele, vakıf, ferağ, fevaid, tevellüd, rakabe kaydı gibi yazma eserlere özgü uygulamalar,

* Yazma eserlerin metin içi düzeni; Türk-İslam Medeniyetinde kitap yazma usül ve adab1, zahriye, mukkadime, dibace, fihrist, serlevha, besmele, hamdele, salvele, bablar, sebeb-i telif, takriz, hatime ve dua, istinsah ve ketebe kaydı, metin içi tezyinatın yer aldığg kitap yazım geleneği,

* Yazı Türleri: talik, rika, sülüs, muhakkak, reyhani, nesih vd.

* Kâğ1t özelliği, filigran türleri,

* Tasvirler, çizimler ve minyatürler, ebced hesabı tarih düşürme, astrolojik ve kehanete dair çizimler, remil, cifir, havass, büyü gibi mistik yaklaşımlar ve sembolizm gibi farklı bölümler sıralanabilir ayrıca burada say1lanların da kendi içinde türlere ayrıldığı da nazar-ı dikkate alınmalıdır.

"Bugün yazma eserler konusu, sadece kütüphanecilik bakımından değil, ilim ve sanat eseri olarak memleketimizin kültür sorunları içinde yer alması gereken çok önemli bir konu olarak karşımıza çıkmaktadır. Bu konuya gereken önemin verilmesi bence milli bir görevdir.” (Bayraktar 1974: 94). Bu ifadeler yaklaşık yarım asır önce yazma eserlerimizin kültür mirası kapsamında ele alınarak gerekli çalışmaların ciddiyetle planlanmasını öngörmekteydi. Aradan uzun zaman geçmiş olmasına rağmen bu ifadeler maalesef bugün de geçerliliğini korumaktadır.

\section{Yazma Eser Kütüphaneciliği}

Ulusal kültürel mirasımızın orijinal kaynakları arasında önemli bir yere sahip olan yazma eserlerimiz sayıca çokluğu, nadirliği, sanatsal özellikleri, içerikleri itibariyle özellikle Türk-İslam medeniyetinin gelişimine tanıklık ve kaynaklık 
ettiği bugün yadsınamaz bir gerçektir. Yazma eserlerden edinilebilecek bilgilere çoğu zaman başka bir kaynaktan ulaşmanın mümkün olmaması ve bu kitapların yitirildiğinde tarihin derinliklerinde bir sır olarak kalmaya mahkûm olması, yazma kitapların diğerlerinden ayrı bir önem ve ciddiyetle korunması ve hizmete sunulmasını gerektirmektedir. Bu durum beraberinde kütüphanecilik ana uzmanlık alanının altında "yazma eser kütüphaneciliği”" gibi zor ve detaylı bir disiplinin ortaya çıkıp geliştirilmesini gerekli kılmaktadır.

Yazma Eser Kütüphaneciliği: Yazma eserlerin araştırmacıyı ilgilendirebilecek tüm özgün unsurlarıyla birlikte uluslararası kabul görmüş başta (MARC) olmak üzere yazma eser kütüphanesinin eserlerini hizmete sunma politikalar1na uygun standartlara tam uyumlu olarak nitelenerek, tüm niteleme unsurlar1 üzerinden erişiminin sağlanması uygulamalarının tümünü içeren kütüphaneciliğin alt disiplinidir. 3 temel faaliyet alanı ise:

I. Depolama: RFID (Radio Frequency Identification/Radyo Frekanslı Tanımlama), Otomatik iklimlendirme, akıllı raflar, kitap koruma kapları, akıllı güvenlik sistemleri vb. Bunlar teknoloji firmaları marifetiyle yapılabilen uygulamalardır.

II. Kataloglama / Niteleme / Kodikoloji: Yazma eserlerin bibliyografik kimliklerinin verilmesinde kullanılabilecek standart niteleme alanları kütüphanecilik ilke ve yöntemleri doğrultusunda kataloglama ve sınıflama kurallarına uygun, MARC veya diğer elektronik kataloglama alanlarına uyumlu olabilecek şekilde oluşturulmalıdır. Uzman, nitelikli personel ve farklı uzmanlık alanlarından işbirliği gerektirir. Önerilen niteleme alanları ve bu alanlara ilişkin alt alanlar aşağıdaki gibidir:

$\checkmark \quad$ Eserin dili / Dil kodu (041)

$\checkmark \quad$ Sira numarası (Bas1lı katalogdaki sira numaras1)

$\checkmark \quad$ Konu/sinıflama numarası (LC, DOS vb.)

$\checkmark$ Demirbaş/derme (koleksiyon) numarası

Eser adt ve sorumluluk bildirimi alanı (100-245-246)

$\checkmark \quad$ Eser adı (Orijinali ve Türkçe transkripsiyonuyla)

$\checkmark$ Yazar-Mü’ellif adı (Orijinali ve Türkçe transkripsiyonuyla)

$\checkmark$ Çoğaltan/Kopyalayan-Müstensih adı (Orijinali ve Türkçe transkripsiyonuyla)

$\checkmark$ Esere katkı yapmış diğer kişilerle ilgili bilgiler (müstensih, mütercim, hattat, muhaşşi vb.) 
$\checkmark \quad$ Yayın bildirimi alanı (260)

$\checkmark \quad$ Te’lîf tarihi ve yeri

$\checkmark \quad$ İstinsah tarihi ve yeri

$\checkmark \quad$ Tercüme tarihi ve yeri

\section{Fiziksel Niteleme Alanı (300)}

$\checkmark$ Cilt sayısı, Yaprak sayısı,

$\checkmark$ Diğer (Yazı türü, yazım türü, satır/sütun sayısı)

$\checkmark \quad$ (Boyutlar) Kâğıt ve yazı alanı boyutu

Yazma eserlerde, fiziksel niteleme alanını iki şekilde ele almak mümkündür: İlki, yazma eserlerin kitap, yani orijinal formattır; ikincisi, hem koruma hem de erişim açısından kolaylık sağladığı bilinen sayısallaştııılmış veya farklı tekniklerle farklı kayıt ortamlarına (medium) aktarılmış kitapdışı-kağıtdışı formattır. Yazma eserlerin nitelenmesinde kullanılması gereken bu üç alt alanın yanı sıra, yazma eserin elde bulunan orijinalinin veya kopyasının ne tür materyal üzerine kaydedildiğinin belirtildiği ve bu materyalin çalışması için gerekli/gerekecek araç - gerecin özelliklerinin belirtildiği Fiziksel Ortam alanı ile RDA alanları olan içerik, medya ve taşıyıcı türü alanları da yazma eserlerin nitelenmesinde kullanılabilmektedir (Anameriç 2016: 441- 442).

Fiziksel niteleme alanı yazma eserlerin daha ayrıntılı olarak tanımlanabilmesine yardımcı olacak bazı alt alanları içermektedir. Bilindiği gibi yazma eser nüshaları aynı müellife ait olsa bile aralarında kâğıt türü/boyutu, yazı türü, yaprak sayısı, satır/sütun sayısı gibi nedenlerle farklılıklar olmaktadır. $\mathrm{Bu}$ farklılıklar eserin tekliği veya nadirliği ile ilgili bazı ipuçlarını verebilecek niteliktedir. Fiziksel niteleme alanına kaydedilen bilgiler sanatsal, fiziksel özellikler belirli bir hiyerarşik düzen ve birbiriyle ilişkili bir bütün içinde kurgulanmalıdır. $\mathrm{Bu}$ şekilde eserin tanımlanması daha sistematik bir yapı içerisinde olabilecektir. Fiziksel niteleme alanında yer alan alt alanlar birer kültürel miras ögesi olan yazma eserlere genel ve özel boyutta;

Uluslararası standartlar çerçevesinde ayrıntılı kataloglama ile daha güvenilir bir bibliyografik denetim yapilabilmesine, daha güvenilir, entegre, kolay bir envanter sistemi geliştirilebilmesine, basılı/elektronik kataloglar ile daha kolay ve etkin bir erişim sağlanmasına, farklı ortama kayıtlı yazma eserlerin hangi ortamlarda ve nasıl saklanacağına veya depolanacağına, bunların hangi saklama veya depolama koşullarında korunması gerektiğine, farklı ortama kayıtlı yazma eserlerin hangi araç, donanım veya aparatlar (media) ile çalıştı- 
rılması/okunması gerektiğinin kütüphane yöneticilerine ve okuyuculara bildirilmesine, kaç adet yazma eserlerin kağıt dışı ortamda olduğunun bilinmesine, yazı türü, yazım türü ve kağıt boyutu bilgileri ile yazma eserlere ilişkin sanatsal özelliklerin belirlenebilmesine ilişkin yazma eserlerin fiziksel özelliklerine yönelik çalışma yapan araştırmacıların / okuyucuların daha ayrıntılı bilgiler edinmesini sağlayarak onların erişimindeki isabet oranını artıracaktır (Anameriç 2016: 461-462).

\section{Notlar Alanı (500)}

$\checkmark \quad$ Sanatsal ve fiziksel özellikler (tezhip, minyatür, kâğıt, cilt, mürekkep)

$\checkmark$ Yazma eserin başlangıç satırları (Besmele'den sonraki birkaç satır)

$\checkmark$ Yazma eserin bitiş satırları (Hatimenin son birkaç satırı)

$\checkmark \quad$ Nüsha bilgisi (Tek nüsha, nadir nüsha, müellif hattı nüsha, orijinal nüsha)

$\checkmark \quad$ Eserin bölümleri ile ilgili bilgiler (eser kaç bölümden oluşur?, bölüm başlıkları)

$\checkmark \quad$ Kayıt bilgileri (fevaid, mütalaa, sema, vakıf, temellük kaydı vb.)

$\checkmark$ Eserin fiziksel durumu (Kondüsyon)

$\checkmark$ Rakabe/Takip/İzleme kelimesi

$\checkmark \quad$ Ketebe Kaydı (Eserin ne zaman, kim ya da kimler tarafindan yazılıp çoğaltıldığına dair bilgiler)

Yazma eserlerin, kendilerini "tek" ve "benzersiz" yapan birden fazla sanatsal, fiziksel ve içerik özellikleri vardır. Bunlar kütüphanecilerin biraz daha serbest, ancak yine de belirli kurallar çerçevesinde kullanacakları "500 (a) Genel Notlar" alanında ve ilgili alt alanlarında nitelendirilebilmektedir. Çünkü bu alanlar kütüphaneciler veya kütüphanecilere yardımcı olabilecek -bir ekip içerisindeki- alan uzmanları (yazma eser uzmanı/kodikolog) tarafından doldurulacak daha özel ve ayrıntılı bilgilerin yer aldığı alanlardır. Yazma eserlerin nitelemesinde kullanılması gereken notlar genel olarak;

a. Sanatsal özellikler

b. Fiziksel özellikler

c. İçerik özellikleri olarak sınıflandırılabilir. Bunlar kendi içlerinde önem sırasına göre tekrar sınıflandırılmalı, yapılacak kataloglama çalı̧̧masında belirlenen standart sıra ile nitelenmesi gerekmektedir. Burada dikkat edilmesi gereken nokta, her eserde notlar alanına girilmesi gereken özelliklerin olup olmadığının belirlenmesidir, bu işlem gereksiz alanların açılmasını ve yan- 
lı̧ tanımlamaların yapılmasını engelleyecektir. Ancak şu da bilinmelidir ki, MARC alanlarında yazmalar için ayrılmış özel bir bölüm ve/veya alt bölüm yoktur, belirlenecek not alanları için kütüphanecinin değerlendirme kapasitesi ve deneyimi önemlidir (Anameriç 2015: 30-31).

Notlar alanında bulunması gereken alt alanlar birer kültürel miras öğesi olan yazma eserlere genel ve özel boyutta; uluslararası standartlar çerçevesinde 3. düzey bir kataloglama ile daha güvenilir bir bibliyografik denetim yapılabilmesi, basılı/elektronik kataloglar ile daha kolay ve etkin bir erişim sağlanmas1, sanatsal - cilt, tezhip ve minyatür -, fiziksel ve içerik özelliklerinin daha ayrıntılı bir biçimde belirlenebilmesi, nadirlik/teklik durumlarının bilinmesinin yanı sıra mülkiyet/sahiplik durumlarının anlaşılması gibi yazma esere maddi ve manevi değer katan birçok unsura erişimi de mümkün kılacaktır (Anameriç 2015: 52-53).

\section{Ek Girișler (700)}

$\checkmark \quad$ Kişi adı konu ek girişleri

$\checkmark \quad$ Coğrafi konu ek girişleri

$\checkmark \quad$ Tarihsel dönem konu ek girişleri

$\checkmark \quad$ Konu ek girişleri

$\checkmark \quad$ Kişi ek girişleri

Bu alandaki ek girişler yazma eser koleksiyonu içerisinde dönemsel, coğrafik ve tematik grupların oluşmasına imkân tanıyarak yazma eserin içeriğine ve nüshasına dair belirleyici bir çerçeve çizilmesini sağlayacaktır. Ayrıca bu alan çoğunlukla konu bazlı araştırma yapan araştırmacıların ilgilendikleri konular ve ilişkili konular ile ilgili yazma eserlerin tümüne erişimi açısından son derece önemlidir.

Linklemeler (800) "Bu alanlar kendi içinde ilişkilendirilmelidir" (Rukancı, Anameriç ve Tuzcu 2016: 346-348).

Yazma eser kütüphaneciliği eserin tam, ayrıntılı ve doğru nitelenmesini kütüphaneciliğin uluslararası standartlarına uygun biçimde uygulamaya koymayı amaç edinmiştir. Yazma eser kütüphaneciliği içinde mütalaa edebileceğimiz, eserin nitelenmesinde çok önemli verilerin ortaya çıkarılmasını sağlayan (codicology) kodikoloji ise bugüne kadar farkındalığı oldukça zayıf ve yeni bir çalışma alanıdır. Bu farkındalığı güçlendirmek için kodikoloji tanımlarının ve kodikolojinin amaçlarının iyi irdelenmesi gerekir: Gacek'e göre kodikoloji, üretiminden günümüze kitapların tüm materyal ve süreçlerini de 
içerecek biçimde bilimsel olarak tanımlanmasıdır. Aynı zamanda "manuscriptology" olarak da bilinir. XX. Yüzyılın ortalarında ortaya çıkmış farklı uzmanlık alanlıklarıyla ilişkili bir disiplindir. Kodikolojik çalışmalar şu sorulara cevap vermeye çalışı:

* Kitap nasıl, ne zaman ve nerede üretilmiştir?

* Üretilme amacı nedir?

* Sahibi kimdir? Kodikoloji daha geniş kapsamda; Yazmanın metne aktarım süreci, hangi koleksiyonlarda, koleksiyonerlerde ve hangi kütüphanelerde bulunduğu gibi eserin tarihi geçmişini ortaya koyacak farklı araştırma süreçlerini de kapsayabilir (2009: 64).

Reitz’e göre kodikoloji yazma eserlerin fiziksel yapısı ve karakteristik özellikleri analiz edilerek eserin aidiyeti, tarihi ve kültürel değerini belirleme bilimidir (Reitz 2018). Batı dünyasında "codex+logy= codicology (kodex bilimi)" kodikoloji olarak bilinen yazma eser bilimi bugün sahip olduğumuz yazma eser koleksiyonlarının tüm yönleriyle tanımlanması açısından oldukça önem taşımaktadır. Kodikoloji faaliyetleri kapsamında yazma esere ilişkin:

* Yaş1, dönemi,

* Ait olduğu kültür ve medeniyet,

* Üretim (yapım) malzemeleri,

* Sanatsal değeri,

* Maddi değeri,

* Manevi değeri,

* Özgünlüğü, orijinalliği hakkında tanımlayıcı (descriptive) bilgiler tespit edilebilir.

Kodikoloji, aynı zamanda kitabın üretimini ve sonrasındaki tarihini daha iyi anlamayı sağlamak amacıyla fiziksel yapısını inceleyen çalışma alanıdır. XIX. yüzyılın sonlarından itibaren, kitap üzerindeki çalı̧̧malar tarihsel gelişimlerin yeniden yapılandırılması için bazı kurallara bağlanmıştır, çünkü kitaplar zamana ve mekâna göre değişiklik gösterirler. Kâğıt tabakasında (quire) kullanılan yaprak sayısı, parşömenin ön ve arka yüzlerinin göreli yapısı, cetvelleme ve delme tarzı (ve bu işlemlerin yapraklar katlanmadan önce veya sonra m1, yoksa bir defada bir veya birden fazla yaprağın m1, yoksa bir şablon yard1mıyla $\mathrm{m}$ gerçekleştirildiği) ve bir kitabın nasıl dikilip bağlandığı değişken özelliklerdir. Bu bağlamda, bir kitabın yapısının incelenmesi; yapım yöntemi, kökeni ve menşei hakkında dikkate değer bir aydınlatma ortaya koyarak ori- 
jinal görünümünü yeniden kurmaya yardımcı olabilir (Brown: 2017). Kodikolojinin Türkçe karşılığını "yazma bilim” olarak öneren Günay Kut'un da belirttiği gibi;

"Osmanlı dönemi yazma eserlerinden Türkçe olanlar tarih olarak 600 yıl geriye götürülebilir. Bu geriye gidiş Arapça ve Farsça eserler için İslamiyet'in ilk dönemlerine kadar uzanmaktadır. Yazma eser kataloglarının belli başlı amac1 bir koleksiyonda veya bir kütüphanede mevcut olan eserlerin kullanımını teşvik etmek ve böylece onları koruyarak araştırıcıların hizmetine sunmaktır. Yazma eserin her yönü ile tavsifi ve tanımlanması uzmanlık işidir. Son zamanlarda Batının bu uzmanlık dalına codicology dediği, bu işi yapan kişileri de codicolog olarak adlandırdığını biliyoruz. Türkçesi ile yazma-bilim ve bu konunun uzmanına yazma-bilimci diyebileceğimiz bu bilim dalı gerçekten de oldukça geniş bir bilgi birikimi gerektirir. Diğer ülkelere göre Türkiye'deki yazma eserler sayı bakımından çokluğu yanı sıra nitelik açısından da yadsınamayacak derecededir. Minyatürlü eserler, tezhipli eserler, müellif hattıyla olanlar, ünlü hattatların elinden çıkanlar, dünyada sadece bizde olanlar, çok eski dönemlere ait olanlar gibi sınıflayabileceğimiz bu yazma eserlerimizi öncelikle kendi bilim adamlarımıza, genç araştırıcılara ve dolayısıyla dünya literatürüne tanıtmamız öncelikle yapılması gereken bir iş olmalıdır"(Kut 1999: 78-82).

Dolayısıyla kodikoloji yazma eserlerimizin doğru ve detaylı bilgilerle nitelenmesinde, erişime sunulmasında tanıtılması, geliştirilmesi ve yaygınlaştırılmas1 gereken bir disiplindir.

Yazma eser kütüphaneciliği kültürel miras aktarımında şu soruların cevapsız kalmasına izin vermemelidir?

* Ülkemizde kaç cilt / adet / tane yazma eser vardır?

* Bunların konu ve alt konu dağılımı nedir?

* Nadir ve ünik nüshalar hangileridir ve nerededir?

* Bu eserlerin dil dağılımı nasıldır?

* Eserlerin alfabe / yazı türü dağılımı nasıldır?

* Bu eserlerin var ise yurtdışındaki nüshaları hangileridir?

* Sanatsal olarak önemli ve değerli olanlar hangileridir?

Tüm bu soruların hem bir koleksiyon hem de tüm koleksiyonlar üzerinden net karşılıklar bulması ve gelecek kuşaklara bu bilgilerin aktarımı uluslararası standartlarda yürütülecek yazma eser kütüphaneciliği faaliyetlerini zorunlu kılmaktadır. 
III. Hizmete Sunma / Erişim: Tanıtım ve yararlanmaya sunmada önemli olan, kullanıcının araştırmasını kolaylaştıracak, hızlandıracak her türlü imkânı sunarken yazma eser kütüphanelerinin sahip olduğu dermenin tüm yönleriyle tanıtılabilmesi ve standart bir hizmet politikasının belirlenmiş olmasidir.

Yazma eserlerin yurtdışındaki örneklerde olduğu gibi görsel unsurlarıyla ve özellikle antik ve kendine özgü değerleriyle kullanıcının beğenisine, araştırmasına sunulabilmesi ve hatta bir adım daha öteye giderek yazma eserlerin çeşitli hediyelik eşyalar üzerinden bile tanıtımının yapılabilmesi ülkemizde henüz mümkün olamamı̧sır.

Yazma eser kütüphanelerinin tanıtımlarının da yeterli düzeyde yapılması gerekir. Bu eserler her ne kadar çoğunlukla araştırmacıların bilimsel çalışmalarına kaynaklık etse de, kültürel mirasa katkı yapan özellikleri nedeniyle de farklı alanlarda araştırma yapan birçok kişinin ilgi alanına giren kaynaklardır. Bu kişiler yazma eser kütüphanelerinin potansiyel kullanıcı grubudur. Kütüphane dermelerinde bulunan koleksiyonların detaylı tanımlamaları ve kategorizasyonları yapıldığı ve bunların web sayfaları üzerinden kullanıcının dikkatine sunulduğu takdirde aktif kullanıcıya dönüşmeleri sağlanacaktır.

Örneğin, İngiltere'de Senate House Library sahip olduğu 21.000'in üzerindeki yazma eseri ait olduğu yer, tarihi, kaynağı ya da mülkiyeti, konusu, kişi adları, diline göre ayrı ayrı listelerde tanıtmaktadır. Ayrıca ilişkili diğer koleksiyonlar hakkında yönlendirme yapılmıstır. Ayrıca koleksiyondan genel olarak hangi konularda ya da ilgili görsellerden bilgi edinebileceği "subject covered include" başlığı altında 8 alt madde ile sıralanmıştır. Yapılan bu çalı̧̧malar kullanııının ilgili yazma eser koleksiyonu hakkında araştırmasında nasıl ve ne ölçüde yararlanabileceği noktasında ilk bakışta fikir sahibi olmasını sağlarken belki de bazı konularda da merakını gidermek amacıyla farklı alanlarla ilgilenebilmesine olanak sağlamaktadır (Senate House 2016; $\mathrm{Ru}-$ kanc1 2016: 525). Bir diğer örnekte ise Amerika Birleşik Devletleri Kongre Kütüphanesi Near East Collections bölümünün yazma ve nadir eserleri hakkında genel bilgiler verdikten sonra dermeyi 35 farklı coğrafi bölge, ülke ve dillerine (42 dil) göre kategorize ettiğini görmekteyiz. Ayrıca Kütüphane "An Illustrated Guide" (Görsel / Resimlendirilmiş Bir Rehber) uygulaması ile yazma ve nadir eserler hakkında tanıtıı bilgileri kitaplardaki görseller eşliğinde sunarak hem katalog araştırmasını daha ilgi çekici, estetik kılmakta hem de araştırmayı daha zevkli ve eğlenceli hale getirmektedir (Near East Collections...2016; Rukanc1 2016: 522). 
Tanıtım ve erişim faaliyetlerinde amaç, araştırmacıların yazma eserlerin araştırmaya değer bulabileceği tüm yönlerinden haberdar edilmesi, ilgilendiği esere çok yönlü ve kolay erişimin sağlanması olmalıdır. Düzenlenecek sergiler, konferanslar vb. etkinlikler de tanıtıma katkı sağlayacaktır. Bu çalışmalar her yıl düzenli olarak oluşturulacak halkla ilişkiler çalışma grubu tarafindan organize edilmeli ve duyurulmalıdır. Bunun yanı sıra koleksiyonun tümü içerik ve fiziksel özellikleri dikkate alınarak kategorize edilmeli her kategori farklı başlık ve sloganlarla tanıtılmalıdır.

Ülkemizde yazma eser koleksiyonlarının tanıtımı için gerekli altyapı çalışmaları henüz oluşturulamamıştır. Zira gerek yazma eser kütüphanesinin tümü gerekse bazı koleksiyonların ayrıntılı bir şekilde tanıtımı için eserlere ilişkin sayı, cilt bilgisi, hangi dillerde olduğu ve genel konu başlıkları oldukça yetersiz kalmaktadır. Yurt dışındaki önemli yazma eser kütüphaneleri koleksiyonlarını kendi içlerinde nadirlik, tematik ilişki, dil, dönem, sanatsal özellikler bağlamında kategorize ederek kullanıcıya özel duruma getirebilmektedir. Sözkonusu yabancı kütüphaneler bu koleksiyon kategorileri için "important collection", "unique collection", "special collection", "art collection", "rare collection", ifadelerini kullanırken ayrıca koleksiyon içerisinde dönem ve dil ayrımı yaparak araştırmaları özelleştirmeyi başarmışlardır. Yazma eser kütüphanelerinde bu tür bir tanıtım ve özelleştirme için her bir eserin detaylı olarak nitelenmesinin yanı sıra eserin tüm niteleme unsurlarından erişimi sağlayacak bir kütüphane yazılımının kullanılması gereklidir. Basılı kitaplar için ve uluslararası standartlar (MARC) temel alınarak oluşturulan kütüphane otomasyonu yazılımları yazma eser kütüphaneleri için yazma eser niteleme unsurları / terminolojisine uygun olarak geliştirildikten sonra kullanımalıdır. Aksi takdirde basılı kitaplar için oluşturulan niteleme alanları yazma eserlerin nitelenmesinde karmaşaya neden olarak ülkemizde zaman zaman "Kur'an-1 Kerim" nüshalarının bile yanlıs kataloglanmasına neden olabilmektedir. Dolayısıyla yazma eser kütüphanelerindeki sunum ve tanıtım faaliyetlerinin zenginleştirilmesi, araştırmacılar için daha kolay ve anlamlı hale getirilebilmesi arka planda yazma eserlerin uluslararası standartlarda tam ve doğru kataloglanması faaliyeti ile doğru orantılı olarak karşımıza çıkmaktadır.

\section{Sonuç}

“Tüm yazma eserlerimiz bizim için çok değerlidir" ifadesi, aslında yazma eserlerin gerçek değerlerini kavrayamayışımızın, ayırt edici özelliklerini tam olarak tespit edemeyişimizin hazin bir göstergesidir. Ayrıca tüm yazma eserlerin özellikleri ve değerlerini bir potada eriterek hepsine aynı kuralları ve tanıtım yöntemlerini uygulamak doğru değildir, kolaycılıktır. Geçmişten ge- 
len depo ya da koruma merkezli anlayış, üzerinde çok yönlü araştırmaların yapılamadığı kitap depolarını bir defineye (hazineye) benzetme avuntusuyla bizi uzun yıllar meşgul edebilir. Yazma eserler cildi, zahriyesi, serlevhası, minyatürleri, kâğıt türü, yazı türü, renkleri, tezyinatı, satır/sütun düzeni, metin içi süslemeleri, hatimesi ve mühürleri ile bir bütündür. Bu bütünün tüm ayrıntılarını ve özelliklerini yazma eserlerin katalog kayıtlarına yansıtabilmek oldukça derin bir bilgi birikimi ve tecrübe gerektirir. Çoğu zaman da bu işin zorluk derecesine göre farklı bilim dallarında uzman kişilerle ortak bir çalışma ve gayret içine girilebilir. Ancak burada vazgeçilmemesi gereken nokta yazma eserin kendi terminolojisi çerçevesinde tüm fiziksel özellikleriyle katalog kaydının çıkarılmasıdır. Nitekim yazma eserler yalnızca bilim dünyası için değil aynı zamanda sanat dünyası için de oldukça önemli tek ya da nadir yapıtlardır. Bu eserlerin katalog kaydındaki fiziksel niteleme alanlarının tam, doğru ve özenli bir şekilde doldurulması ilgili eserin araştırmacılar için hangi niteliklere sahip bir kaynak olduğunun duyurulması açısından gereklidir. Bunun yanı sıra sözgelimi eserin eşsiz sanatsal niteliklere sahip olduğunun tespiti onun daha iyi korunması için gerekli tedbirlerin alınması için harekete geçilmesini sağlayacaktır. Böylece yapılacak olan fiziksel niteleme yazma eserin gerçek değeriyle araştırmacıları buluşturacak ve eserin herhangi bir nedenle maddi değer kaybına uğramasını önleyecektir.

Zira yazma eserler bizim kültürel mirasımızdır, onları en iyi şekilde niteleyip tanıtmak görevini de büyük bir ciddiyet, işbirliği içinde yapabilmek için "alan uzmanlığı" ya da "mesleki liyakatı" ön plana çıkarmaktan başka çaremiz yoktur.

Yazma eser kütüphanelerinin mevcut durumda organizasyonundaki en önemli sorun "bilginin organizasyonu" sorunudur. Eserlere ait bibliyografik kimliklerin verilmesinde ve hazırlanan kataloglarda yer alan kayitlardaki niteleme alanları arasındaki farklılıklar hem kullanıcıların kaynaklara etkin erişimini engellemekte hem de kütüphanecilerin bibliyografik denetimini zorlaştırmaktadır. Bunun için standart niteleme alanlarının belirlenmesi gerekmektedir. Belirlenecek bu alanların yazma eserlerin sahip olduğu özellikleri tümüyle yansıtması gerekmektedir. Yazma eserler bizim kültürel mirasimızdır, onları en iyi şekilde niteleyip tanıtmak görevini de büyük bir ciddiyet, işbirliği içinde yapabilmek için "alan uzmanlığı" ya da "mesleki liyakatı" ön plana çıkarmanın önemi yadsınamaz. Böylesine tarihi ve manevi bir sorumluluk bir takım çekişmelere kurban edilememeli, bilimin ve aklın rehberliğinde hareket edilmelidir. Bu bağlamda kısa ve orta vadede aşağıda sıralanan öneriler hayata geçirilebilir: 
Bilgi ve Belge Yönetimi Bölümlerinde mezunlarına "yazma eser kütüphanecisi-kodikolog" unvanı verecek lisans ve lisansüstü programların oluşturulması.

$\checkmark \quad$ Bilgi ve Belge Yönetimi Bölümü mezunu yazma eser kütüphanelerinden sorumlu yöneticilerin atanması.

$\checkmark \quad$ Milli Kütüphane ve Yazma Eserler Kurumu Başkanlığının ortaklaşa yürüteceği yazma eserlere ilişkin otorite dizini ve konu başlıkları listesinin hazırlanması

$\checkmark$ Yazma Eserler Toplu Kataloğu'nun uluslararası standartlara uygun olarak revize edilmesi ve tamamlanmasi.

$\checkmark$ Yazma Eser Terimleri Sözlüğünün hazırlanması,

$\checkmark$ Yazma Eser Kütüphanecilerinin diğer uzmanlarla (doğu dilleri, sanat tarihi, edebiyat, ilahiyat vb.) işbirliğini sağlayacak bir "Yazma Eser Kütüphaneciliği Platformu" nun oluşturulması.

$\mathrm{Bu}$ hedef ve faaliyetler zaman alabilir ancak doğru planlandığında ve uygulandığında ulaşılması zor hedefler olarak görülmemelidir. Yazma eserlerin kültürel mirasın önemli bir tamamlayıcısı olması yalnızca yazma eserlerin varlı̆̆ı ile açıklanabilecek bir konu değildir. Hatta yazma eserlerin sayıca çokluğu ya da çok eski dönemlere kadar tarihlenmesi bile çoğu zaman belirleyici olmayabilir. Söz konusu eserlerin ait oldukları dönemin bilimsel, kültürel ve sanatsal özelliklerinin tam ve doğru olarak belirlenebilmesi onları kültürel mirasın bir parçası olarak değerlendirilmesine olanak tanıyacaktır. Bu özelliklerin belirlenmesi ise kütüphanecilikte niteleme ve tanımlama faaliyeti olarak karşımıza çıkar. Bu faaliyette teorik altyapı ve uzmanlık dalları arasındaki işbirliği yanı sıra usta-çırak ilişkisi diye de bilinen tecrübenin önemi göz ardı edilmemelidir. Zira konuya ilişkin teorik bilgiler kimi zaman daha önce yazma eserleri incelemiş kişiler için yeterli olmayabilir. Özellikle bu eserlerin kültürel unsurları arasında sayabileceğimiz fiziksel ve sanatsal özelliklerinin tanımlanması oldukça uzun bir süre yazma eserlere aşina olmayı gerektirmektedir. Bu noktada yapılması gereken kritik uygulama yazma eser uzmanlarının özellikle lisans eğitimlerini tamamlamadan önce yazma eser kütüphanelerinde uygulama yapma imkânına sahip olmalarıdır. Nitekim farklı disiplinler arasında işbirliğini zorunlu kılan yazma eser kütüphaneciliği aynı zamanda uygulamalı eğitimin de belirleyici olabileceği oldukça zor ve karmaşık bir uzmanlık alanıdır. 


\section{Kaynaklar}

Anameriç, Hakan (2015). "Yazma Eserlerin Kataloglanmasında MARC Standard 500 Genel Notlar Alanı ve Bileşenlerinin Kullanımı", $A n-$ kara Üniversitesi Dil ve Tarih-Coğrafya Fakültesi Dergisi 55. 2: 27-58 (2016). "Yazma Eserlerin Kataloglanmasında MARC Standard 300 Fiziksel Niteleme Alanı ve Bileşenlerinin Kullanımı”, $A n-$ kara Üniversitesi Dil ve Tarib-Coğrafya Fakültesi Dergisi 56. 2 (2016): 440-464.

Bayraktar, Nimet. (1974). "Kütüphanelerimizde Yazma Eserler”, Türk Kütüphaneciler Derneği Bülteni 23.2 (1974): 94-130.

Brown, Michelle P. (2017). “Codicolog” In Understanding Illuminated Manuscripts: A Guide to Technical Terms (80-90). London: J. Paul Getty Museum: Malibu and British Library. 1994. Web. 27.07.2017.

Cunbur, Müjgân (1970). "Yazma Kütüphanelerimiz Bugünkü Durumları ve Meseleleri”, Türk Kütüphaneciler Derneği Bülteni 19. 1 (1970): 3-17.

Gacek, Adam. (2009). Handbook of Oriental Studies Arabic Manuscripts: A Vademecum for Readers. Leiden-Boston: Brill.

Kut, Günay (1999). "Yazma Eserler ve Türkiye Toplu Kataloğu Çalısmaları" 21. Yüzynla Doğru Türk Kütüphaneciliği 35. Kütüphane Haftası Bildirileri içinde (78-85). Haz.: Özlem Bayram, Erhan Erkan, Erol Y1lmaz. Ankara: Türk Kütüphaneciler Derneği, 1999.

"Near Esat Collections Library of Congress An Illustrated Guide". Web. 17 Şubat 2014.

Reitz, Joan M. ODLIS Online Dictionary for Library and Information Science, Web 25.09.2016.

Rukancı Fatih (2016). "Yazma Eser Koleksiyonlarının Tanıtımı", ÜNAK 2014 Uluslararası Kültürel Mirasın ve Kültürel Bellek Kurumlarn Yönetimi Kongresi Bildirileri içinde (517-526). Web. 04.03.2016.

Rukanc1, Fatih, Hakan Anameriç ve Kemal Tuzcu (2016). Yazma Eserlerin Bibliyografik Denetimi. İstanbul: Hiperlink,

"Senate House Library Palaeography \& Manuscript Studies and Print Studies" (2016). Web. 28.03.2016. 
